\title{
PENDIDIKAN KARAKTER UNTUK SISWA SD DALAM PERSPEKTIF ISLAM
}

\author{
Ani Nur Aeni \\ PGSD Kelas Universitas Pendidikan Indonesia Kampus Sumedang \\ Jl. Mayor Abdurachman No. 211 Sumedang \\ Email: aninuraeni220876@yahoo.com
}

\begin{abstract}
Character education in elementary school is an attempt to build character Elementary Students. Character education can be called as akhlak (moral) education, which aims to establish akhlak karimah. The foundation of character education in Islam is the Quran and Hadith. The process of character education to elementary school students should be tailored to the stage of development and the formation of character at this age, in elementary operations can use the model Tadzkirah (Teladan=Exemplary, Arahkan=Aim, Dorongan=Encouragement, Zakiyah=purify, Kontinuitas=Continuity, Ingatkan=Remind, repitition, Organize, Heart). Keywords: character education, akhlak (moral), tadzkirah.
\end{abstract}

ABSTRAK

Pendidikan karakter di SD merupakan sebuah upaya untuk membangun karakter Siswa SD. Pendidikan Karakter dapat disebut sebagai pendidikan Akhlak, yang bertujuan untuk membentuk akhlak karimah. Landasan pendidikan karakter dalam Islam adalah al-Quran dan Hadits. Proses pendidikan karakter kepada siswa SD harus disesuaikan dengan tahap perkembangan dan pembentukan karakter pada usia ini, dalam operasionalnya di SD dapat menggunakan model TADZKIRAH (Teladan, Arahkan, Dorongan, Zakiyah, Kontinuitas, Ingatkan, Repitition, Organisasikan, Heart).

Kata kunci: pendidikan karakter, akhlak, tadzkirah.

PENDAHULUAN Pendidikan Karakter menjadi isu yang sangat hangat terhitung mulai dari diberlakukannya pendidikan karakter secara nasional di semua jenjang pendidikan diawali dari tingkat sekolah dasar. Dalam berbagai forum ilmiah banyak dibahas dan didiskusikan tentang pendidikan karakter.

Sementara dalam Islam pendidikan karakter bukan perkara baru. Dalam diskursus pendidikan Islam, pendidikan karakter memiliki istilah tersendiri yaitu pendidikan akhlak. Bagaimana pendidikan karakter dalam perspektif Islam khususnya untuk siswa SD? Dalam tulisan ini akan dibahas mengenai hal tersebut.

\section{PENGERTIAN KARAKTER DAN PENDIDIKAN KARAKTER}

Sebelum membahas pendidikan karakter, terlebih dahulu dipaparkan tentang pengertian karakter. Istilah karakter diambil dari bahasa
Yunani "Charassian" yang berarti "to mark" atau menandai dan memfokuskan bagaimana mengaplikasikan nilai kebaikan dalam bentuk tindakan atau tingkah laku, sehingga orang yang tidak jujur, kejam, rakus dan perilaku jelek lainnya dikatakan orang berkarakter jelek. Sebaliknya, orang yang perilakunya sesuai dengan kaidah moral disebut dengan berkarakter mulia.

Pengertian karakter menurut Pusat Bahasa Depdiknas adalah "bawaan, hati, jiwa, kepribadian, budi pekerti, perilaku, personalitas, sifat, tabiat, temperamen, watak". Adapun berkarakter, adalah berkepribadian, berperilaku, bersifat, dan berwatak.

Imam Al-Ghazali menganggap karakter lebih dekat kepada akhlak, yaitu spontanitas manusia dalam bersikap, atau melakukan perbuatan yang telah menyatu dalam diri manusia sehingga ketika muncul tidak perlu dipikirkan lagi. 
Sementara Ki Hajar Dewantara (dalam Wibowo, 2013, p. 34) memandang bahwa karakter itu sebagai watak atau budi pekerti. Koesoema (2007, p. 80) menyebutkan bahwa jika karakter dipandang dari sudut behavioral yang menekankan unsur somatopsikis yang dimiliki individu sejak lahir, maka karakter dianggap sama dengan kepribadian.

Karakter dipengaruhi oleh hereditas, sebagaimana dinyatakan oleh Samani \& Hariyanto (2013) bahwa karakter dapat dimaknai sebagai nilai dasar yang membangun pribadi seseorang, terbentuk baik karena pengaruh hereditas maupun pengaruh lingkungan, yang membedakannya dengan orang lain, serta diwujudkan dengan sikap dan perilakunya dalam kehidupan sehari-hari.

Sementara untuk pengertian pendidikan karakater Lickona (1992) menyebutkan "character education is the deliberate effort to help people understand, care about, and act upon core ethical values", hal ini berarti bahwa pendidikan karakter adalah upaya yang disengaja untuk membantu orang memahami, peduli, dan bertindak berdasarkan nilai-nilai etika inti.

Pendidikan Karakter adalah pendidikan yang mendukung perkembangan sosial, emosional, dan etis siswa. Dirjen Dikti (dalam Barnawi \& Arifin, 2013) menyebutkan bahwa pendidikan karakter dapat dimaknai sebagai pendidikan nilai, pendidikan budi pekerti, pendidikan moral, pendidikan watak, yang bertujuan mengembangkan kemampuan peserta didik untuk memberikan keputusan baik-buruk, memelihara apa yang baik, mewujudkan, dan menebar kebaikan itu dalam kehidupan seharihari dengan sepenuh hati. Semantara secara sederhana pendidikan karakter dapat dimaknai sebagai hal postif apa saja yang dilakukan guru dan berpengaruh kepada karakter siswa yang diajarnya (Samani \& Hariyanto, 2013).

Pendidikan karakter merupakan sebuah upaya untuk membangun karakter (character building). Elmubarok (2008, p. 102) menyebutkan bahwa carakter building merupakan proses mengukir atau memahat jiwa sedemikian rupa, sehingga berbentuk unik, menarik, dan berbeda atau dapat dibedakan dengan orang lain, ibarat sebauh huruf dalam alfabeta yang tak pernah sama antara yang satu dengan yang lain, demikianlah orang-orang yang berkarakter dapat dibedakan satu dengan yang lainnya.

Pendidikan karakter dapat disebut juga sebagai pendidikan moral, pendidikan nilai, pendidikan dunia afektif, pendidikan akhlak, atau pendidikan budi pekerti.

\section{POSISI PENDIDIKAN KARAKTER DALAM PENDIDIKAN NASIONAL}

Secara Eksplisit Pendidikan Karakter merupakan amanat UU No 20 Tahun 2003 Tentang Sistem Pendidikan Nasional yang menegaskan bahwa:

Pendidikan nasional berfungsi mengembangkan kemampuan dan membentuk watak serta peradaban bangsa yang bermartabat dalam rangka mencerdaskan kehidupan bangsa, bertujuan untuk berkembangnya potensi peserta didik agar menjadi manusia yang beriman dan bertaqwa kepada tuhan Yang Maha Esa, berakhlak mulia, sehat, berilmu, cakap, kreatif, mandiri dan menjadi warga negara yang demokratis serta bertanggung jawab.

Tujuan pendidikan nasional tersebut jika dianalisis dari sudut taxonomi Bloom dan pendidikan karakter maka terlihat sebagai berikut.

Tabel 1. Analisis Taxonomy Bloom Terhadap Tujuan Pendidikan

\begin{tabular}{|c|l|l|l|}
\hline No & \multicolumn{1}{|c|}{ Unsur Tujuan } & \multicolumn{1}{|c|}{ Taxonomy Bloom } & \multicolumn{1}{c|}{ Pendidikan Karakter } \\
\hline 1. & membentuk watak bangsa & $\begin{array}{l}\text { Afektif tingkat tinggi } \\
\text { (characterizing) }\end{array}$ & $\begin{array}{l}\text { Membentuk pribadi berbudaya dan } \\
\text { religius }\end{array}$ \\
\hline 2. & $\begin{array}{l}\text { membentuk peradaban } \\
\text { bangsa }\end{array}$ & $\begin{array}{l}\text { Afektif tingkat tinggi } \\
\text { (characterizing) }\end{array}$ & Membangun moral bangsa yang beradab \\
\hline 3. & $\begin{array}{l}\text { beriman dan bertakwa } \\
\text { kepada Tuhan Yang Maha } \\
\text { Esa }\end{array}$ & $\begin{array}{l}\text { Afektif tingkat tinggi } \\
\text { (characterizing) }\end{array}$ & $\begin{array}{l}\text { Membentuk manusia yang beriman dan } \\
\text { bertaqwa }\end{array}$ \\
\hline 4. & berakhlak mulia & $\begin{array}{l}\text { Afektif tingkat tinggi } \\
\text { (characterizing) }\end{array}$ & Membentuk pribadi yang kaffah \\
\hline 5. & sehat, & psikomotor & Membentuk manusia yang sehat jasmani \\
\hline
\end{tabular}




\begin{tabular}{|l|l|l|l|}
\hline & & & dan rohani \\
\hline 6. & berilmu & $\begin{array}{l}\text { Afektif tingkat tinggi } \\
\text { (evaluation) }\end{array}$ & $\begin{array}{l}\text { Membentuk manusia dengan } \\
\text { kemampuan intelektual dan daya kritis } \\
\text { yang tinggi }\end{array}$ \\
\hline 7. & cakap, kreatif & $\begin{array}{l}\text { Kognitif, afektif, } \\
\text { psikomotor }\end{array}$ & $\begin{array}{l}\text { Membentuk manusia dengan } \\
\text { kemampuan intelektual dan daya kritis } \\
\text { yang tinggi }\end{array}$ \\
\hline 8. & mandiri & $\begin{array}{l}\text { Kognitif, afektif, } \\
\text { psikomotor }\end{array}$ & Membentuk pribadi yang kaffah \\
\hline 9. & $\begin{array}{l}\text { Kognitif, afektif, } \\
\text { psikomotor }\end{array}$ & Membentuk pribadi yang kaffah \\
\hline 10 & bertanggung jawab & $\begin{array}{l}\text { Kognitif, afektif, } \\
\text { psikomotor }\end{array}$ & Membentuk pribadi yang kaffah \\
\hline
\end{tabular}

(Diadaptasi dari Sumantri:, 2009: 19).

\section{LANDASAN PENDIDIKAN KARAKTER}

Pendidikan karakter dalam Islam berlandaskan kepada Al-Quran dan Hadits. Berikut beberapa ayat al-quran dan hadits yang berbicara tentang karakter:

Dan (ingatlah) ketika Luqman berkata kepada anaknya, di waktu ia memberi pelajaran kepadanya: "Hai anakku, janganlah kamu mempersekutukan Allah, sesungguhnya mempersekutukan (Allah) adalah benar-benar kezaliman yang besar (Q.S. 31: 13).

Hai anakku, dirikanlah shalat dan suruhlah (manusia) mengerjakan yang baik dan cegahlah (mereka) dari perbuatan yang mungkar dan bersabarlah terhadap apa yang menimpa kamu. Sesungguhnya yang demikian itu termasuk halhal yang diwajibkan (oleh Allah) (Q.S. 31: 17).

Dan janganlah kamu memalingkan mukamu dari manusia (karena sombong) dan janganlah kamu berjalan di muka bumi dengan angkuh. Sesungguhnya Allah tidak menyukai orang-orang yang sombong lagi membanggakan diri (Q.S. 31: 18).

Dan sederhanalah kamu dalam berjalan dan lunakkanlah suaramu. Sesungguhnya seburukburuk suara ialah suara keledai (Q.S. 31: 19).

Jadikanlah kata-kata pertama yang diucapkan seorang anak kalimat Laa ilaaha illallah, dan bacakanlah kepadanya menjelang maut, kalimat laa ilaaha illallah (HR. Ibnu Abbas).

Muliakanlah anak-anakmu dan didiklah mereka dengan adab (budi pekerti) yang baik (HR. Ibnu Majah).
Suruhlah anak-anakmu menjalankan shalat jika mereka sudah berusia tujuh tahun. Dan jika mereka sudah berusia sepuluh tahun, maka pukullah mereka jika tidak mau shalat. Dan pisahkanlah tempat tidurnya (HR. Al-Hakim dan Abu Daud, diriwayatkan dari Ibnu Amr bin AlAsh).

Anas berkata bahwa Rasulullah bersabda: Anak itu pada hari ketujuh dari kelahirannya disembelih akikahnya, serta diberi nama dan disingkirkan dari segala kotoran-kotoran. Jika ia telah berusia 6 tahun ia dididik beradab susila, jika ia telah berumur 9 tahun dipisahkan tempat tidurnya dan jika berumur 13 tahun dipukul agar mau shalat. Jika ia telah berumur 16 tahun boleh dikawinkan, setelah itu ayah berjabatan tangan dengannya dan mengatakan: saya telah mendidik, mengajar, dan mengawinkan kamu, saya mohon perlindungan kepada Allah dari fitnah-fitnah di dunia dan siksaan di akhirat (HR. Ibnu Hibban)

\section{NILAI-NILAI DALAM PENDIDIKAN KARAKTER}

Ada 18 butir nilai-nilai pendidikan karakter yang telah dirumuskan oleh Depdiknas yaitu, Religius, Jujur, Toleransi, Disiplin, Kerja Keras, Kreatif, Mandiri, Demokratis, Rasa Ingin Tahu, Semangat Kebangsaan, Cinta tanah air, Menghargai prestasi, Bersahabat/komunikatif, Cinta Damai, Gemar membaca, Peduli lingkungan, Peduli social, Tanggung jawab.

Sementara para pakar pendidikan, seperti Megawangi (2004) mengelompokkan karakter ke dalam 9 pilar, yaitu (1) cinta tuhan dan ciptaannya, (2) kemandirian dan tanggung jawab, (3) kejujuran, amanah, dan bijaksana, (4) 
hormat dan santun, (5) dermawan, suka menolong, dan gotong royong, (6) percaya diri, kreatif, dan pekerja keras, (7) kepemimpinan dan keadilan, (8) baik dan rendah hati, (9) toleransi, kedamaian dan kesatuan.

Samani \& Hariyanto (2013) menyebutkan bahwa Direktorat Pendidikan Lanjutan Pertama Direktorat Jendral Pendidikan Dasar dan Menengah Departemen Pendidikan dan Kebudayaan dalam Pendampingan Guru Sekolah Swasta Tradisional (Islam) telah menginventarisasi domain budi pekerti Islami sebagai nilai-nilai karakter yang harus ditampilkan, yaitu terhadap Tuhan, terhadap diri sendiri, terhadap keluarga, terhadap orang lain, terhadap masyarakat dan bangsa, dan terhadap alam lingkungan.

Nilai karakter terhadap Tuhan meliputi: 1) Iman dan taqwa, 2) Syukur, 3) Tawakal, 4) Ikhlas, 5) Sabar, 6) Mawas diri, 7) Disiplin, 8) Berfikir jauh kedepan, 9) Jujur, 10) Amanah, 11) Pengabdian,12) Susila, 13) Beradab.

Nilai karakter terhadap diri sendiri meliputi: 1) Adil, 2) Jujur, 3) Mawas Diri, 4) Disiplin, 5) Kasih Sayang, 6) Kerja Keras, 7) Pengambil Risiko, 8) Berinisiatif, 9) Kerja Cerdas, 10) Kreatif, 11) Berfikir Jauh Kedepan, 12) Berfikir Matang, 13) Bersahaja, 14) Bersemangat, 15) Berfikir Konstruktif, 16) Bertanggung Jawab, 17) Bijaksana, 18) Cerdik, 19) Cermat, 20) Dinamis, 21) Efisien, 22) Gigih, 23) Tangguh, 24) Ulet, 25) Berkemauan Keras, 26) Hemat, 27) Kukuh, 28) Lugas, 29) Mandiri, 30) Menghargai Kesehatan, 31) Pengendalian Diri, 32) Produktif, 33) Rajin, 34) Tekun, 35) Percaya Diri, 36) Tertib, 37) Tegas, 38) Sabar, 39) Ceria/Periang.

Nilai karakter terhadap keluarga meliputi: 1) Adil, 2) Jujur, 3) Disiplin, 4) Kasih Sayang, 5) Lembut Hati, 6) Berfikir Jauh Ke depan, 7) Berfikir Konstruktif, 8) Bertanggung Jawab, 9) Bijaksana, 10) Hemat, 11) Menghargai Kesehatan, 12) Pemaaf, 13) Rela Berkorban, 14) Rendah Hati, 15) Setia, 16) Tertib, 17) Kerja Keras, 18) Kerja Cerdas, 19) Amanah, 20) Sabar, 21) Tenggang Rasa, 22) Bela Rasa/Empati, 23) Pemurah, 24) Ramah Tamah, 25) Sopan Santun, 26) Sportif, 27) Terbuka.

Nilai karakter terhadap orang lain meliputi: 1) Adil, 2) Jujur, 3) Disiplin, 4) Kasih Sayang, 5) Lembut Hati, 6) Bertanggung Jawab, 7) Bijaksana, 8) Menghargai, 9) Pemaaf, 10) Rela
Berkorban, 11) Rendah Hati, 12) Tertib, 13) Amanah, 14) Sabar, 15) Tenggang Rasa, 16) Bela Rasa, 17) Pemurah, 18) Ramah Tamah, 19) Sopan Santun, 20) Sportif, 21) Terbuka.

Nilai karakter terhadap masyarakat dan bangsa meliputi: 1) Adil, 2) Jujur, 3) Disiplin, 4) Kasih Sayang, 5) Kerja Keras, 6) Lembut Hati, 7) Berinisiatif, 8) Kerja Keras, 9) Kerja Cerdas, 10) Berfikir Jauh ke depan, 11) Berfikir Konstruktif, 12) Bertanggung Jawab, 13) Bijaksana, 14) Menghargai Kesehatan, 15) Produktif, 16) Rela Berkorban, 17) Setia/Loyal, 18) Tertib, 19) Amanah, 20) Sabar, 21) Tenggang Rasa, 22) Bela Rasa, 23) Pemurah, 24) Ramah Tamah, 25) Sikap Hormat.

Nilai karakter terhadap lingkungan meliputi: 1) Adil, 2) Amanah. 3) Disiplin, 4) Kasih Sayang, 5) Kerja Keras, 6) Berinisiatif, 7) Kerja Cerdas, 8) Berfikir Jauh kedepan, 9) Berfikir Konstruktif, 10) Bertanggung Jawab, 11) Bijaksana, 12) Menghargai Kesehatan, Kebersihan, 13) Rela Berkorban.

\section{KONSEP PENDIDIKAN KARAKTER MENURUT PARA FILOSOF MUSLIM}

Sebagaimana telah dibicarakan sebelumnya bahwa dalam diskursus pendidikan Islam pendidikan karakter disebut dengan pendidikan akhlak. Para filosof muslim telah berbicara mengenai hal ini, seperti yang dinyatakan AlFarabi bahwa akhlak yang baik hanyalah terwujud dengan pengawasan diri terus menerus, pendidikan seharusnya diarahkan pada pembinaan akhlak, pemberian pelajaran yang mungkin dipergunakan untuk tujuan yang buruk hendaklah dicegah sedapat mungkin.

Hal ini dikuatkan pula oleh pernyataan Imam Al-Ghazali bahwa pendidikan itu menghilangkan akhlak yang buruk dan menanamkan akhlak yang baik, bahkan alGhazali menegaskan bahwa tujuan yang paling penting dari pendidikan itu adalah taqarrub ilallah. Sementara Syeikh Az-Zarnuji menggariskan bahwa selain pengabdian kepada Tuhan tujuan pendidikan diarahkan untuk pembentukan moral, pribadi, intelektual dan kesehatan jasmani serta pembentukan sikap mental kemasyarakatan amar makruf nahyi munkar dengan rasa tanggung jawab terhadap kesejahteraan masyarakat, bersih dari pamrih pribadi. 
Hal yang hampir sama dinyatakan pula oleh Ibnu Maskaiwaihi (dalam Madjidi, 1997, p. 33) bahwa cita-cita pendidikan adalah terwujudnya pribadi susila, berwatak yang lahir dari perilakuperilaku luhur atau berbudi pekerti yang mulia. Dari budi (jiwa/watak) lahir pekerti (perilaku) mulia. Sementara Ibnu Sina mengemukakan bahwa alat pendidikan budi pekerti itu berupa hadiah dan hukuman, kelembutan dan kekerasan. Ibnu Sina sangat menekankan agar para pendidik menjauhkan anak didiknya dari akhlak yang buruk, kebiasaan yang jelek dengan jalan targhib wa tarhib dengan lunak atau kasar, dengan jalan memperdulikan atau membiarkan, sesekali memberikan pujian atau celaan, cara ini digunakan jika dipandang sudah cukup.

\section{MODEL PENDIDIKAN KARAKTER}

Majid \& Andayani (2012) telah merumuskan berbagai model pendidikan karakter salah satunya adalah model TADZKIRAH (dibaca tadzkiroh). Secara etimologis tadzkirah berasal dari bahasa Arab dzakkara yang berarti ingat, dan tadzkirah artinya peringatan. Adapun makna tadzkirah dalam hal ini adalah suatu model pembelajaran yang diturunkan dari sebuh teori pendidikan Islam, tadzkirah mempunyai makna:

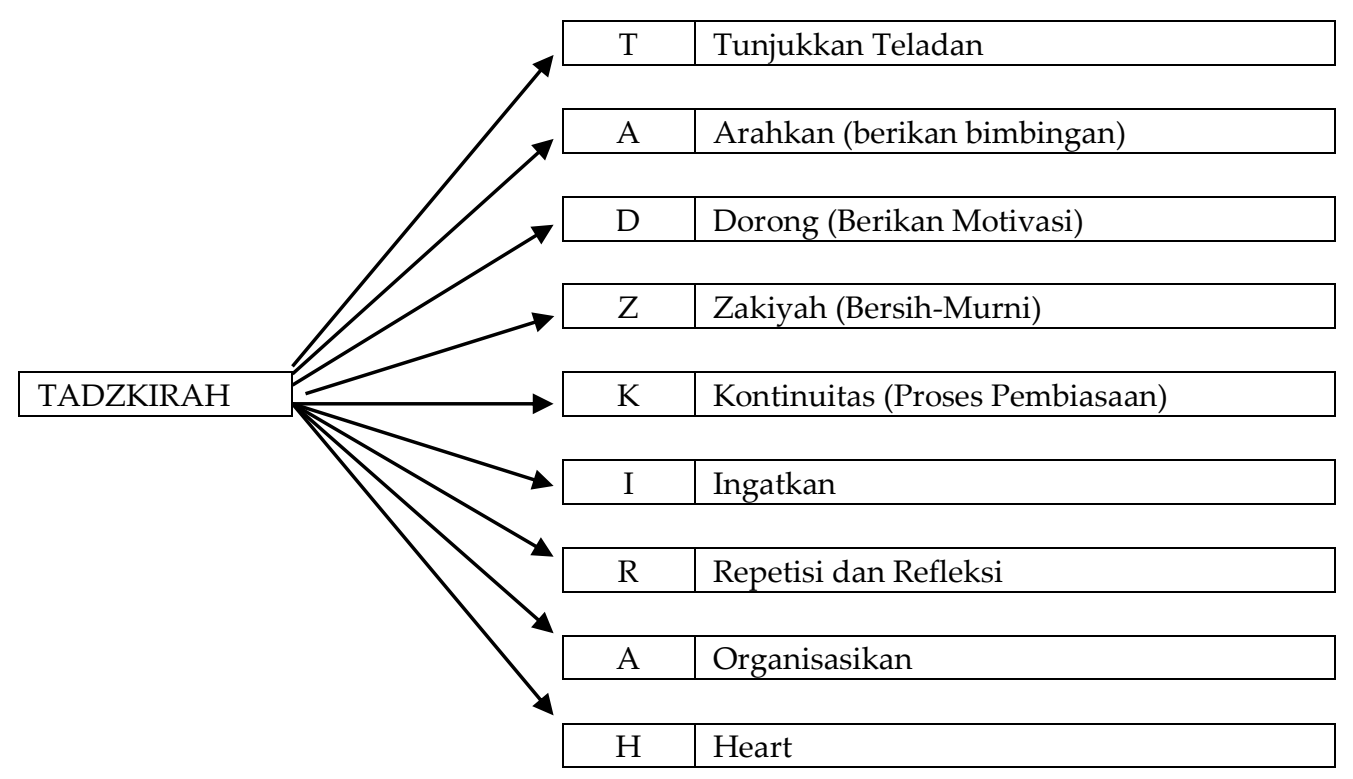

Bagan 1. Model Tadzkirah

\section{Tunjukkan Teladan}

Para guru pada tahap ini wajib menunjukkan teladan kepada siswa, hal ini menuntut para guru untuk menjadi suri teladan, maka metode keteladanan dalam hal ini digunakan. Tafsir (2005: 143) mengungkapkan

Keteladanan itu ada dua macam, yaitu disengaja dan tidak disengaja. Keteladanan yang tidak disengaja adalah keteladanan dalam keilmuan, kepemimpinan, sifat keikhlasan, dan sebangsanya, sedangkan keteladanan yang disengaja ialah seperti memberikan contoh membaca yang baik, mengerjakan salat yang benar. Keteladan yang disengaja ialah keteladan yang memang disertai penjelasan atau perintah agar meneladaninya, keteladanan yang tidak disengaja dilakukan secara tidak formal, keteladanan yang disengaja dilakukan secara formal

Walaupun keteladan ini dianggap sebagai cara yang kuno dalam pendidikan namun terbukti keteladan ini sangat efektif terhadap perubahan sikap dan perilaku (Aeni: 2009). Demikian pula Ulwan (1999) menguatkan bahwa "keteladanan dalam pendidikan merupakan metode yang berpengaruh dan terbukti paling berhasil atau membekas dalam mempersiapkan dan membentuk aspek karakter, moral, spiritual, dan etos sosial anak".

"Tunjukkan teladan" juga berarti para guru harus mampu menunjukkan kepada siswa tokoh-tokoh yang pantas untuk diteladani, karena yang menjadi persoalan saat ini adalah terjadinya krisis keteladanan dimana para siswa menurut Azra (2010) kesulitan dalam mencari 
contoh teladan yang baik (uswah hasanah) atau living moral exemplary di lingkungan sekolah.

\section{Arahkan (Berikan Bimbingan)}

Berdasarkan pada tahap perkembangan, siswa SD sudah mulai mengenai baik-buruk, benar-salah, yang diperintahkan-yang dilarang, maka dalam hal ini anak harus diberikan arahan atau bimbingan untuk mencapai baik, benar, dan yang diperintahkan itu, jangan sampai anak salah memilih dan salah menentukan.

\section{Dorong (Berikan Motivasi)}

Pemberian motivasi oleh para guru sangat penting dilakukan dalam rangka membangkitkan semangat dan menumbuhkan rasa percaya diri pada siswa. Dalam pemberian motivasi ini tepat sekali jika menggunakan metode targhib wa tarhib, yaitu metode pemberian motivasi agar siswa melakukan kebaikan (targhib) dan agar menjauhi kejahatan (tarhib). Metode ini hampir mirip sama dengan metode reward and punishment (ganjaran dan hukuman), namun Tafsir (2005) membedakan keduanya bahwa targhib wa tarhib bersandarkan ajaran Allah, sedangkan reward and punishment bersandarkan pada hukuman dan ganjaran manusiwi.

Pemberian motivasi ini juga dalam rangka pemenuhan kebutuhan siswa sebagai manusia yang memiliki need untuk dihargai. Teori motivasi yang dirumuskan oleh Maslow (dalam Jarvis, 2009) menggambarkan hirarki kebutuhan manusia sebagai berikut.

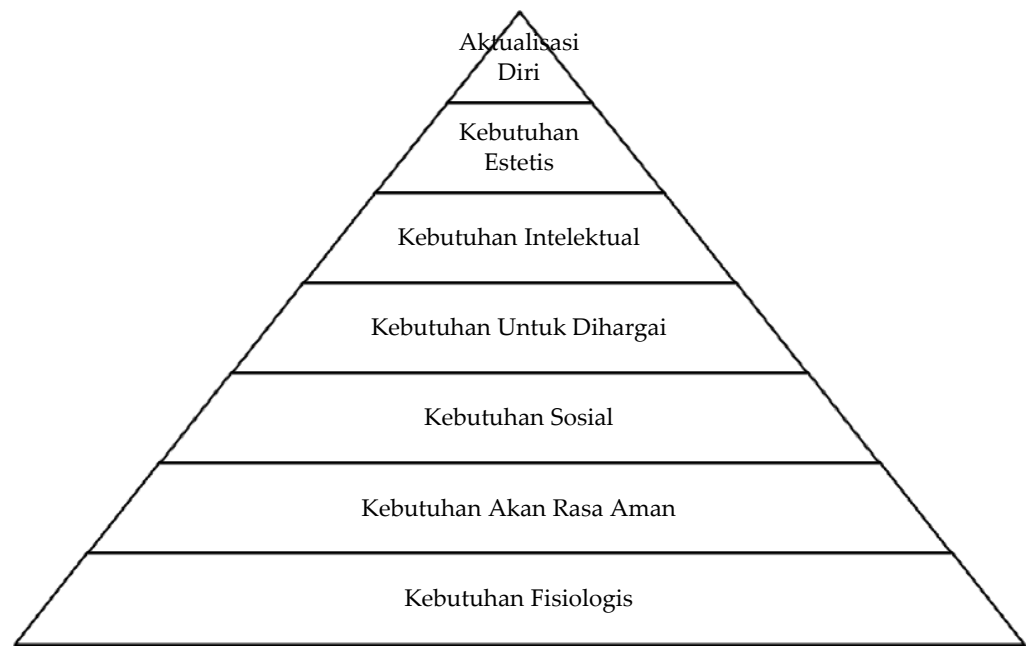

Gambar 1. Hirarki Kebutuhan Menurut Maslow

\section{Zakiyah (Bersih-Murni)}

Para guru harus memiliki hati yang bersih (ikhlas) dalam memberikan bimbingan dan arahan kepada anak. Segala sesuatu jika berangkat dari hati yang ikhlas tidak akan terasa berat. Keihlkasan ini bukan hanya harus ada pada setiap guru, demikian pula pada diri siswa harus ditanamkan. Ikhlas dalam belajar, bersikap, dan berbuat sekecil apapun. Jika rasa ikhlas sudah tumbuh, maka keikhlasan ini akan menjadi kekuatan yang maha dahsyat yang akan merubah segala perilaku dalam kehidupan.

\section{Kontinuitas (Proses Pembiasaan)}

Pada langkah ini metode yang digunakan adalah metode pembiasaan, walaupun sebagian orang menganggap bahwa metode pembiasaan itu sangat konvensional tetapi dipandang hal ini sangat efektif dalam memberikan pendidikan yang berkaitan dengan moral. Tafsir (2005) menyebutkan bahwa "pembiasaan sebenarnya berintikan pengalaman, dan inti dari pembiasaan itu adalah pengulangan". Dalam metode pembiasaan ini yang dibiasakan adalah hal-hal yang baik, sehingga akan menjadi akhlak baik, dimana perilaku baik itu akan muncul secara spontan dan reflek tanpa memerlukan pertimbangan dan pemikiran. Karena hal inilah ahli pendidikan sepakat bahwa metode pembiasaan ini dibenarkan sebagai salah satu upaya pendidikan dalam pembentukan manusia dewasa.

\section{Ingatkan}


Pepatah Arab mengatakan bahwa al-insanu mahallu al-khata wa al-nisyan artinya manusia itu tempatnya salah dan lupa, karena itu manusia harus diingatkan: jika berbuat kesalahan harus ditegur supaya menyadari kesalahannya, jika melalaikan kewajiban harus diingatkan. Inilah yang harus dilakukan oleh para guru. Demikian juga para guru harus mengingatkan kepada siswa bahwa senatiasa kita berada dalam pengawasan Allah (muraqobatullah), dampaknya para siswa akan senantiasa menjaga sikap dan perilakunya dari perbuatan yang tercela.

\section{Repetisi dan Refleksi (Pengulangan)}

Pengulangan dalam proses pembelajaran dilakukan dengan tujuan supaya siswa terbiasa, untuk mengingat kembali, dan untuk memahami suatu perkataan. metode pengulangan ini berlandaskan kepada hadits bahwa Rasulullah jika mengucapkan suatu kalimat selalu mengulangnya sampai tiga kali dengan tujuannya supaya para pendengar dapat memahaminya. Pengulangan ini akan sangat erat kaitannya dengan metode pembiasaan.

Secara kajian ilmiah pengulangan ini memberikan dampak yang hebat, sebagaimana yang dikutip oleh Aswandi (2010)

Para pakar neurofisiologi menyimpulkan temuan mereka, yakni otak mempunyai kemampuan yang menakjubkan untuk menerima pikiran atau perilaku yang berulang-ulang dan menyambungkannya ke pola-pola atau kebiasaan-kebiasaan yang otomatis dan dibawah sadar, semakin sering mengulangi pikiran dan tindakan yang konstruktif, pikiran atau tindakan itu akan menjadi semakin mendalam, semakin cepat, dan semakin otomatis.

\section{Organisasikan}

Yang dimaksud "organisasikan" disini adalah bahwa guru dituntut memiliki kemampuan untuk mengorganisasikan pengetahuan dan pengalaman yang diperoleh siswa di luar sekolah dengan yang diperoleh di sekolah melalui proses belajar. Hal ini bertujuan supaya informasi yang akan disampaikan dan informasi yang didapat guru adalah informasi yang tepat sesuai dengan keadaan siswa, informasi inilah yang akan dijadikan bahan dalam proses pembelajaran yang akan dilaksanakan.

\section{Heart}

Karena pendidikan karakter itu termasuk pendidikan pada dunia afektif maka yang harus diolah dari diri siswa adalah olah rasa dan olah hati. Lakukan proses pendidikan kepada siswa dengan menyentuh sisi yang paling sensitif yaitu qalbu/hati. Dan ketika menyentuh sisi ini harus dilakukan dengan qalbu pula. Ini dapat dikatan proses pendidikan oleh hati untuk hati.

Dikarenakan pada langkah ini instrument yang digunakan adalah hati, maka tatalah hati degan sebaik-baiknya, karena segala perbuatan baik-buruknya akan berangkat dari hati sebagaimana sabda rasul bahwa "ingatlah sesungguhnya dalam diri manusia ada segumpal darah, yang apabila ia beres maka bereslah seluruh persoalan, tetapi apabila ia rusak, maka rusaklah seluruhnya, ingatlah bahwa dia itu hati"

\section{KARAKTERISTIK SISWA SD DARI SUDUT PERKEMBANGAN MORAL}

Dalam Peraturan Pemerintah tentang Pendidikan Dasar Bab VIII tentang Siswa Pasal 15 ayat 1 dinyatakan bahwa Untuk dapat diterima sebagai siswa Sekolah Dasar seseorang harus berusia sekurang-kurangnya enam tahun, dan berdasarkan PP yang sama pada Bab I tentang Ketentuan Umum Pasal 2 disebutkan bahwa Pendidikan dasar merupakan pendidikan Sembilan tahun, terdiri atas program pendidikan enam tahun di Sekolah Dasar dan program pendidikan tiga tahun di Sekolah Lanjutan Tingkat Pertama, hal ini dapat disimpulkan bahwa siswa SD berusia antara 6-12 tahun.

Menurut Peaget anak usia 6-12 tahun ini berada pada tahap moralitas otonomi, ditandai dengan Anak menilai perilaku atas dasar tujuan yang mendasarinya. konsep anak tentang keadilan mulai berubah. Gagasan yang kaku dan tidak luwes mengenai benar dan salah, yang dipelajari dari orang tua, secara bertahap dimodifikasi. Akibatnya, anak mulai mempertimbangkan keadaan tertentu yang berkaitan dengan suatu pelanggaran moral. Misalnya bagi anak usia 5 tahun berbohong selalu "buruk", tapi anak yang lebih besar menyadari bahwa berbohong dibenarkan dalam situasi tertentu dan karenanya tidak selalu "buruk". Lebih jelasnya karakteristik ini dapat dilihat pada tabel berikut 
Tabel 2. Teori Tahap Perkembangan Moral Piaget

\begin{tabular}{|c|c|c|}
\hline Umur & Tahap & Ciri Khas \\
\hline 4-7 tahun & $\begin{array}{l}\text { Realisme moral } \\
\text { (pra operasional) }\end{array}$ & $\begin{array}{l}\text { 1. Memusatkan pada akibat-akibat perbuatan } \\
\text { 2. Aturan-aturan tak berubah } \\
\text { 3. Hukuman atas pelanggaran bersifat otomatis }\end{array}$ \\
\hline $7-10$ tahun & $\begin{array}{l}\text { Masa transisi (konkret- } \\
\text { operasional) }\end{array}$ & Perubahan secara bertahap ke pemilikan moral tahap kedua \\
\hline $\begin{array}{l}11 \text { tahun } \\
\text { Ke atas }\end{array}$ & $\begin{array}{l}\text { Otonomi moral, realisme } \\
\text { dan resiprositas (formal } \\
\text { operasional) }\end{array}$ & $\begin{array}{l}\text { 1. Mempertimbangkan tujuan-tujuan perilaku moral } \\
\text { 2. Menyadari bahwa aturan moral adalah kesepakatan tradisi } \\
\text { yang dapat berubah }\end{array}$ \\
\hline
\end{tabular}

(Sumber: Suprabowo, 2008).

\section{TAHAP-TAHAP PENGEMBANGAN DAN PEMBENTUKAN KARAKTER}

Majid \& Andayani (2012) membagi tahap perkembangan karakter berdasarkan Islam kedalam:

1. Tauhid (usia 0-2 tahun)

2. Adab (usia 5-6 tahun)

3. Tanggung Jawab (7-8 tahun)

4. Caring/Peduli (9-10 tahun)

5. Kemandirian (11-12 tahun)

6. Bermasyarakat (13 Tahun)

Berdasarkan klasifikasi tersebut maka pendidikan karakter harus disesuaikan dengan tahap-tahap pertumbuhan dan perkembangan anak.

\section{Tauhid (usia 0-2 tahun)}

Manusia dilahirkan ke dunia dalam kondisi fitrah, maknaya dianugrahi potensi tauhid, yaitu meng-Esa-kan Allah dan berusaha terus untuk mencari ketauhidan tersebut. Pada saat bayi lahir sangat penting untuk memperdengarkan kalimat-kalimat tauhid ini dalam rangka tetap menjaga ketauhidan, sampai bayi menginjak usia 2 tahun sudah diberi kemampuan untuk berbicara, maka kata-kata yang akan keluar dari mulutnya adalah kata-kata tauhid/kalimat thayyibah sebagaimana yang sering diperdengarkan kepadanya.

\section{Adab (usia 5-6 tahun)}

Menurut Hidayatullah sebagaimana yang dikutip oleh Majid \& Andayani (2012), pada fase ini anak dididik budi pekerti, terutama yang berkaitan dengan nilai-nilai karakter jujur (tidak berbohong), mengenal yang baik-buruk, benarsalah, yang diperintahkan-yang dilarang.

\section{Tanggung Jawab (7-8 tahun)}

Berdasarkan hadits tentang perintah shalat pada usia tujuh tahun menggambarkan bahwa pada fase ini anak dididik untuk bertanggung jawab. Jika perintah shalat itu tidak dikerjakan maka akan mendapat sanski, dipukul (pada usia sepuluh tahun).

\section{Caring/Peduli (9-10 tahun)}

Setelah anak memiliki rasa tanggung jawab, maka akan muncul sifat kepedulian, baik kepedulian terhadap lingkungan maupun kepedulian terhadap sesama. Bila bercermin kepada tarikh Rasulullah $S A W$ bahwa pada usia 9 tahun Rasul menggembalakan kambing. Pekerjaan menggembala kambing merupakan wujud kepedulian rasul terhadap kondisi kehidupan ekonomi pamannya, yang pada saat itu mengurusnya setelah kematian kakeknya.

\section{Kemandirian (11-12 tahun)}

Pada usia ini anak telah memiliki kemandirian. Kemandirian ini ditandai dengan siap menerima resiko jika tidak mentaati peraturan. Contoh kemandirian pada pribadi rasul adalah saat beliau mengikuti pamannya untuk berniaga ke negeri Syam. Pada saat itu Rasulullah telah memiliki kemandirian yang hebat, tidak cengeng, kokoh, sampai mau mengikuti perjalanan yang jauh dengan pamannya tersebut, hingga pada saat itu seorang pendeta Bukhaira menemukan tanda-tanda kenabian pada beliau.

\section{Bermasyarakat (13 Tahun)}

Pada fase ini anak sudah mulai memiliki kemampuan untuk bermasyarakat dengan berbekal pengalaman-pengalaman yang didapat pada fase-fase sebelumnya. Kehidupan dalam masyarakat lebih kompleks dari kehidupan keluarga, anak anak mengenal banyak karakter 
manusia selain karakter orang-orang yang dia temui di dalam keluarganya.

Jika merujuk kepada klasifikasi perkembangan karakter tersebut, anak usia SD ada pada fase tanggung jawab (7-8), peduli (910), dan kemandirian (11-12). Pada usia 7-8 diawalai dengan perkenalan anak pada lingkungan baru di sekolah, yang sebelumnya anak hanya mengenal lingkungan rumah, maka pada fase ini anak harus mampu beradaptasi dengan lingkungan baru, anak mulai memiliki rasa tanggung jawab terhadap tugas barunya yaitu belajar dan mengenal lingkungan baru.

Pada usia 9-10 tahun memasuki fase peduli, karena pada fase sebelumnya anak sudah mulai mengenal lingkungan barunya, maka mereka bertemu dengan banyak orang dan menemukan berbagai peristiwa di lingkungan, muncullah rasa kepedulian baik terhadap sesama maupun kepedulian terhadap lingkungan

Pada usia 11-12 anak sudah mulai mandiri, jika dilihat dari usia sekolah pada fase ini merupakan persiapan anak untuk memasuki jenjang pendidikan berikutnya (SMP).

\section{SIMPULAN}

Pendidikan Karakter merupakan amanat Undang undang No 20 Tahun 2003. Dalam Islam pendidikan karakter memiliki istilah tersendiri, yaitu pendidikan akhlak. Para filosof muslim merumuskan bahwa tujuan dari pendidikan bermuara pada akhlak. Siswa SD sangat penting mendapatkan pendidikan karakter mengingat pada usia ini siswa harus sudah memiliki sikap tanggung jawab, kepedulian dan kemandirian sesuai dengan tahap perkembangan moral mereka. Pendidikan Karakter dalam Islam berlandaskan kepada Al-Quran dan Hadits, dalam operasionalnya di SD dapat menggunakan model TADZKIRAH (Teladan, Arahkan, Dorongan, Zakiyah, Kontinuitas, Ingatkan, Repitition, Organisasikan, Heart).

\section{REFERENSI}

\section{Al-Quran}

Al-Hadits

Aeni. Ani Nur. (2009). Respons Mahasiswa Terhadap Kegiatan Tutorial PAI dan Pengaruhnya Terhadap Penghayatan Nilainilai Agama Islam (Studi Kasus di UPI). Tesis pada Program Magister SPS UPI. Tidak diterbitkan.

Aswandi. (2010). Membangun Bangsa Melalui Pendidikan Berbasis Karakter. K@ta: Pendidikan Karakter.

Azra, Azyumardi. (2000). Pendidikan Akhlak dan Budi Pekerti: Membangun Kembali Anak Bangsa. Makalah dalam Konvensi Nasional Pendidikan Tahun 2000. Jakarta: Universitas Negeri.

Barnawi \& Arifin, A. (2013). Strategi \& Kebijakan Pembelajaran Pendidikan Karakter. Jogyakarta: Ar-Ruzz Media.

Elmubarok, Z. (2008). Membumikan Pendidikan Nilai. Bandung: Alfabeta.

Jarvis. M. (2009). Teori-teori Psikologi. (SPATeamwork). Bandung: Nusa Media.

Koesoema, D. (2007). Pendidikan Karakter Strategi Mendidik Anak di Zaman Global. Jakarta: PT. Grasindo.

Lickonna. T. (1992). Education for Character, How Our Schools Can Teach Respect and Responsibility. New York: Bantam Books.

Madjidi, B. (1997). Konsep Kependidikan Para Filosof Muslim. Yogyakarta: Al Amin Press.

Majid, A \& Andayani, D. (2012). Pendidikan Karakter Perspektif Islam. Bandung: PT. Remaja Rosdakarya.

Megawangi, R. (2004). Pendidikan Karakter, Solusi yang Tepat untuk Membangun Bangsa. Jakarta: Indonesia Heritage Foundation.

Samani, M \& Hariyanto. (2013). Konsep dan Model Pendidikan Karakter. Bandung: PT. Remaja Rosdakarya.

Sumantri, E. (2009). Pendidikan Umum. Bandung: Prodi PU UPI.

Suprabowo. (2008). Teori Perkembangan Moral. Retrieved March 3, 2014, from http://novinasuprobo.wordpress.com.

Tafsir. A. (2005). Ilmu Pendidikan Dalam Perspektif Islam. Bandung: PT. Remaja Rosdakarya.

Ulwan. N. A. (1981). Tarbiyyatu al Aulad fi al Islam. Beirut: Dar al salam li al-Tiba'ah wa li al-Nasyr wa al-Tawzi'.

Wibowo, A. (2013). Pendidikan Karakter di Perguruan Tinggi. Yogyakarta: Pustaka Pelajar. 